\title{
Sistem dan Prosedur Akuntansi Kredit Produktif pada PT Bank Pembangunan Daerah Jambi Cabang Muara Bulian: Suatu Tinjauan
}

\author{
Fauziah \\ STIE Graha Karya Muara Bulian
}

\begin{abstract}
The purpose of this study is to find out the system and procedures for credit accounting for the provision of productive credit to customers/debtors of PT. Jambi Regional Development Bank Muara Bulian Branch which has been compiled in accordance with Financial Accounting Standards Number 31 and Bank Indonesia Circular Letter Number 14/26/BKDU. The method used is descriptive method that is by comparing the prevailing theory, in this case the Statement of Financial Accounting Standards Number 31 concerning Banking Accounting and Circular Letter of Bank Indonesia Number 14/26/BKDU Compared with credit procedures at PT. Jambi Regional Development Bank Muara Bulian Branch. The results of this paper indicate that credit accounting procedures on the provision of productive credit to customers/debtors of PT. Jambi Regional Development Bank Muara Bulian Branch has been carried out effectively and efficiently in accordance with applicable principles and regulations.
\end{abstract}

Keyword: system; regional development; Credit Accounting Procedure

DOI: 10.33087 /ekonomis.v3i1.57

\section{PENDAHULUAN}

Industri perbankan telah mengalami perubahan besar dalam beberapa tahun terakhir ini. Perbankan di Indonesia memiliki peranan penting dalam perekonomian negara, yaitu sebagai lembaga perantara keuangan. Secara garis besar, perbankan didirikan dengan tujuan memudahkan masyarakat dalam bertransaksi keuangan dengan menggunakan layananlayanan banking yang telah disediakan oleh perbankan itu sendiri (adisetiawan, 2018). Tidak hanya itu, perbankan juga didirikan dengan maksud dan tujuan untuk mendapatkan laba atau keuntungan yang optimal melalui penggunaan kekayaan atau aset yang dimiliki secara efektif dan efisien. Menurut Undang-Undang No.10 Tahun 1998 bank adalah usaha yang menghimpun dana dari masyarakat dalam bentuk simpanan dan menyalurkan kepada masyarakat dalam bentuk kredit dan atau bentuk lainnya dalam rangka meningkatkan taraf hidup rakyat banyak. Menurut Undang-Undang No.10 tahun 1998 menyebutkan bahwa Kredit adalah "penyediaan uang atau tagihan yang dapat dipersamakan dengan itu, berdasarkan persetujuan atau kesepakatan pinjam-meminjam antara bank dengan pihak lain yang mewajibkan pihak peminjam untuk melunasi utangnya setelah jangka waktu tertentu dengan pemberian bunga (adisetiawan, 2017). Banyak kemudahan yang didapat dari kredit untuk nasabah itu semua tentunya tidak terlepas dari sistem dan prosedur akuntansi yang baik dan memenuhi prinsip atau peraturan yang telah ditetapkan oleh PT. Bank Pembanguan Daerah Jambi.

\section{Tinjauan Pustaka \\ Akuntansi perbankan}

Dalam akuntansi perbankan, pencatatan yang dilakukan berada di ruang lingkup perbankan.Akun-akun yang digunakan juga merupakan akun khusus didunia perbankan. Sama halnya dengan akuntansi keuangan, akuntansi perbankan juga menyajikan laporan untuk pihak internal dan eksternal. Menurut Pernyataan Standard Akuntansi Keuangan (PSAK) No. 31 tentang akuntansi perbankan, akuntansi keuangan dan akuntansi perbankan saling berkaitan, karena memperhatikan karakteristik dan perkembangan usaha bank setelah adanya kebijakan deregulasi dan agar pihak-pihak yang berkepentingan dapat mengikuti perkembangan usaha bank, diperlukan informasi keuangan bank yang dapat memberikan gambaran mengenai keadaan bank secara wajar. Untuk itu diperlukan suatu standard akuntansi keuangan yang khusus berlaku bagi perbankan.

\section{Perkreditan}

Istilah Kredit berasal dari bahasa latin yaitu credo,yang artinya I Belive, I Trust, saya percaya atau saya menaruh kepercayaan. Perkatan credo berasal dari kombinasi perkataan sansekerta cred yang berarti kepercayaan (Trust) dan perkataan latin do yang artinya saya menaruh. Sesudah kombinasi tersebut menjadi bahasa latin, kata kerjanya dan kata bendanya masing-masing menjadi credere dan creditium . meskipun banyak penulis mngemukakan bahwa credit berasal dari credere. 


\section{Fungsi Kredit}

Kredit mempunyai peranan yang sangat penting dalam perekonomian. Secara garis besar, fungsi kredit didalam perekonomian, perdagangan, dan keuangan dapat dikemukakan sebagai berikut: Kredit dapat meningkatkan utility (daya guna) dari modal/uang; Kredit meningkatkan utility (daya guna) suatu barang; Kredit meningkatkan peredaran dan lalu lintas uang; Kredit menimbulkan kegairahan berusaha masyarakat; Kredit sebagai alat stabilitas ekonomi; Kredit sebagai jembatan untuk peningkatan nasional; dan Kredit sebagai alat hubungan ekonomi internasional

\section{Jenis-jenis kredit}

Jenis-jenis kredit dibedakan menjadi beberapa sudut pendekatan, antara lain berdasarkan tujuan kegunaannya, jangka waktunya, macamnya, sektor perekonomian, agunan, golongan ekonomi, serta penarikan dan pelunasannya. Berikut ini kami sampaikan penjelasan dari masing-masing jenis kredit tersebut:

a) Jenis Kredit Menurut Segi Kegunaan: Kredit Investasi, Kredit Modal Kerja; Kredit Konsumsi, Kredit Serba Guna,

b) Jenis Kredit Menurut Segi Tujuan Kredit: Kredit Konsumtif, Kredit produktif, Kredit Modal Kerja atau Kredit Perdagangan, Kredit Investasi,

c) Jenis Kredit Menurut Jangka Waktu: Kredit Jangka Pendek, Kredit Jangka Menengah, Kredit Jangka Panjang

d) Jenis Kredit Dilihat dari Segi Jaminan: Kredit Jaminan Orang, Kredit Jaminan Efek, Kredit Jaminan Barang, Kredit Jaminan Dokumen

e) Jenis Kredit Menurut Segi Bentuknya: Kredit rekening Koran bebas. Kredit rekening Koran terbatas, Kredit rekening Koran aflopend, Revolving credit, Term Loans.

f) Jenis Kredit Menurut dari Segi Sektor Usaha: Kredit Pertanian, Kredit Perindustrian Kredit Pertambangan, Kredit Ekspor Impor, Kredit Koperasi, Kredit Profesi, Kredit Perumahan,

\section{Prinsip-Prinsip Kredit}

Sebelum suatu fasilitas kredit diberikan maka bank harus merasa yakin bahwa kredit yang diberikan harus benar-benar akan kembali. Keyakinan tersebut diperoleh dari hasil penelitian kredit sebelum kredit tersebut disalurkan. Penelitian kredit oleh bank dapat dilakukan dengan berbagai cara untuk mendapatkan keyakinan tentang nasabahnya, seperti melalui prosedur penilaian yang benar dan sungguh-sungguh. Dalam melakukan penilaian kriteria-kriteria serta aspek penilaian tetap sama. Biasanya kriteria penilaian yang umum harus dilakukan oleh bank untuk mendapatkan nasabah yang benar-benar layak untuk diberikan, dilakukan dengan analisis $5 \mathrm{C}$ dan $7 \mathrm{P}$.

1. Character. Character merupakan sifat atau watak seseorang. Sifat atau watak dari seseorang yang akan diberikan kredit benar-benar harus dipercaya. Dalam hal ini bank meyakini benar bahwa calon debiturnya memiliki reputasi baik, artinya selalu menepati janji dan tidak terlibat hal-hal yang berkaitan dengan kriminalitas, misalnya penjudi, pemabuk, atau penipu. Untuk dapat membaca sifat atau watak dari calon debitur dapat dilihat sari latar belakang nasabah, baik yang bersifat latar belakang pekerjaan maupun yang bersifat pribadi seperti cara hidup atau gaya hidup yang dianutnya, keadaan keluarga, hobi dan jiwa sosial.

2. Capacity. Capacity adalah analisis untuk mengetahui kemampuan nasabah dalam membayar kredit. Bank harus mengetahui secara pasti atas kemampuan calon debitur dengan melakukan analisis usahanya dari waktu ke waktu. Pendapatan yang selalu meningkat diharapkan kelak mampu melakukan pembayaran kembali atas kreditnya. Sedangkan bila diperkirakan tidak mampu, bank dapat menolak permohonan dari calon debitur. Capacity sering juga disebut dengan nama Capability.

3. Capital. Capital adalah kondisi kekayaan yang dimiliki oleh perusahaan yang dikelola calon debitur. Bank harus meneliti modal calon debitur selain besarnya juga strukturnya. Untuk melihat penggunaan modal apakah efektif, dapat dilihat dari laporan keuangan (neraca dan 
laporan rugi laba) yang disajikan dengan melakukan pengukuran seperti dari segi likuiditas dan solvabilitasnya, rentabilitas dan ukuran lainnya.

4. Condition. Pembiayaan yang diberikan juga perlu mempertimbangkan kondisi ekonomi yang dikaitkan dengan prospek usaha calon nasabah. Penilaian kondisi dan bidang usaha yang dibiayai hendaknya benar-benar memiliki prospek yang baik, sehingga kemungkinan kredit tersebut bermasalah relatif kecil.

5. Collateral. Collateral merupakan jaminan yang diberikan calon nasabah baik yang bersifat fisik maupun yang nonfisik. Jaminan hendaknya melebihi jumlah kredit yang diberikan. Jaminan juga harus diteliti keabsahannya, sehingga jika terjadi sesuatu, maka jaminan yang dititipkan akan dapat dipergunakan secepat mungkin.

Selanjutnya penilaian suatu kredit dapat pula dilakukan dengan analisis $7 \mathrm{P}$ kredit dengan unsur penilaian sebagai berikut:

1. Personality, yaitu menilai nasabah dari segi kepribadiannya atau tingkah lakunya sehari-hari maupun kepribadiaannya di masa lalu. Penilaian personality juga mencakup sikap, emosi, tingkah laku dan tindakan nasabah dalam menghadapi suatu masalah dan menyelesaikannya.

2. Party, yaitu mengklasifikasikan nasabah ke dalam klasifikasi atau golongan-golongan tertentu berdasarkan modal, loyalitas, serta karakternya sehingga nasabah dapat digolongkan ke golongan tertentu dan akan mendapatkan fasilitas kredit yang berbeda pula dari bank.

3. Perpose, yaitu mengetahui tujuan nasabah dalam mengambil kredit termasuk jenis kredit yang diinginkan nasabah. Tujuan pengambilan kredit dapat bermacam-macam sesuai kebutuhan. Sebagai contoh apakah untuk modal kerja, investasi, konsumtif, produktif dan lain-lain.

4. Prospect, yaitu untuk menilai usaha nasabah di masa yang akan datang apakah menguntungkan atau tidak dengan kata lain mempunyai prospek atau sebaliknya. Hal ini penting mengingat jika suatu fasilitas kredit yang dibiayai tanpa mempunyai prospek, bukan hanya bank yang rugi akan tetapi juga nasabah.

5. Payment, merupakan ukuran bagaimana cara nasabah mengembalikan kredit yang telah diambil atau dari sumber mana saja dana untuk pengembalian kredit. Semakin banyak sumber penghasilan debitur maka akan semakin baik. Sehingga jika salah satu usahanya merugi akan dapat ditutupi oleh usaha lainnya.

6. Profitabillity. untuk menganalisis bagaimana kemampuan nasabah dalam mencari laba. Profitability diukur dari periode ke periode, apakah akan tetap sama atau akan semakin meningkat, apalagi dengan tambahan kredit yang akan diperolehnya.

7. Protection. tujuannya adalah bagaimana menjaga agar kredit yang diberikan mendapatkan jaminan perlindungan, sehingga kredit yang diberikan benar-benar aman. Perlindungan yang diberikan oleh debitur dapat berupa jaminan barang atau orang atau jaminan asuransi.

\section{Pengertian produktif}

Pengertian produktif juga didefinisikan oleh beberapa para ahli, diantaranya yaitu:

a. Menurut Kusriyanto (1984), Produktif merupakan nisbah atau rasio antara hasil kegiatan (output) dan segala pengorbanan (biaya) untuk mewujudkan hasil tersebut (input).

b. Menurut Revianto (1985) juga mendefinisikan bahwa produktif adalah suatu konsep yang menujukkan adanya kaitan antara hasil kerja dengan satuan waktu yang dibutuhkan untuk menghasilkan produk seorang tenaga kerja.

c. Sinungan (2005) mendefinisikan produktif adalah suatu kegiatan yang bersifat universal yang bertujuan untuk menyediakan lebih banyak barang dan jasa untuk lebih banyak manusia, dengan menggunakan sumber-sumber real yang makin sedikit.

Definisi diatas dapat disimpulkan bahwa kredit produktif adalah kredit yang bertujuan untuk memungkinkan debitur dapat mencapai tujuannya apabila tanpa kredit tersebut tidak dapat diwujudkan. Kredit produktif merupakan bentuk kredit yang bertujuan untuk 
memperlancar proses produksi, mulai saat pengumpulan bahan mentah, pengolahan dan sampai kepada proses penjualan barang-barang yang sudah jadi.

\section{PEMBAHASAN \\ Sistem Dan Prosedur Akuntansi Kredit Produktif PT. Bank Pembangunan Daerah Jambi Cabang Muara Bulian}

PT. Bank Pembangunan Daerah Jambi Cabang Muara Bulian merupakan salah satu bank yang menghimpun dana dari masyarakat dan menyalurkan dana tersebut kepada masyarakat/pengusaha. Salah satu nya adalah memberikan pinjaman berupa kredit kepada masyarakat umum, tentunya kredit tidak terlepas dari sebuah kepercayaan kedua belah pihak guna menghindari penyelewengan yang melanggar peraturan perkreditan yang berlaku. Sistem dan prosedur kredit pada PT. bank pembanguan daerah jambi dilakukan secara tersusun dalam standar pelaksanaannya.Adapun tahap-tahap yang dilakukan pihak bank untuk meningkatkan targetnya dalam memberikan kredit.

1. Dalam mempromosikan produk bank jambi,marketing memberikan informasi kepada calon debitur, apa saja syarat untuk mengajukan pinjaman, seperti kelengkapan identitas, surat persetujuan keluarga, jaminan, biaya (administrasi, materai, dan asuransi) dan sebagainya.

2. Kemudian calon debitur memberikan surat permohonan secara tertulis.

3. Surat permohonan tersebut diteruskan kepada pemimpin cabang unutk diketahui dan didisposisi dengan jelas.

4. Account officer meneliti surat permohonan, lalu segera ditentukan apakah permohonan tersebut dapat dipertimbangkan atau ditolak.

5. Apabila surat permohonan itu dapat dipertimbangkan maka debitur akan dipanggil untuk melakukan wawancara dan meyakini kondisi dari calon debitur apabila diperlukan. Sekaligus penyerahan persyaratan yang telah diinformasikan sebelumnya.

6. Pada tahapan ini, pelaksana taksasi akan melakukan perhitungan terhadap jaminan yang diberikan oleh debitur dan menyerahkannya kepada notaris.

7. Setelah berjalan dengan lancar marketing akanmengunjungi tempat yang merupakan jaminan yang diserahkan oleh debitur guna untuk melakukan survey.

8. Selanjutnya, setelah survey dilaksanakan dengan baik, pelaksana account ofiicer bertugas memperoses pembuatan akad/perjanjian kredit atau disebut juga analisis kredit, karena setiap perjanjian harus dilakukan secara tertulis sebagi mana yang tertera dalam Surat Edaran Bank Indonesia No. 14/26/BKDU.

9. Debitur akan dipanggil kembali oleh pelaksana admin kredit untuk melakukan perjanjian antara debitur dan pihak bank dengan cara menandatangani akad/analisis kredit tersebut di atas materai. Dan debitur diperkenankan membawa buku tabungan dan materai dgn jumlah tertentu.

10. Pelaksana akuntansi pelaporan akanmelakukan pencairan terhadap kredit tersebut.

11. Perjanjian antar bank dan debitur selanjutnya akan disetujui oleh Kepala operasional dan pemimpin cabang.

12. Hari selanjutnya debitur akan diminta datang kembali ke kantor bank jambi untuk mengambil buku tabungan yang telah diserahkan dihari sebelumnya yang apabila debitur memerlukanpengambilan uang miliknya pada saat-saat yang diinginkan.

Sebagai sampel, berikut adalah uraian penilaian jaminan yang di serahkan kepada pihak bank jambi yaitu dari salah satu debitur yang menggunakan produk kredit produktif dari bank jambi yaitu Bapak Ansori dari Desa Sungai Baung RT. 03, Kecamatan Muara Bulian, Kabupaten Batang Hari. Pada saat permintaan kredit, pelaksana account officer akan menanyakan kepada calon debitur tentang jaminan/agunan yang akan diserahkan sebagai salah satu syarat dalam perjanjian kredit yang selanjutnya oleh bagian taksasi akan melakukan perhitungan atau penilaian terhadap kelayakannya. Tim penilai apparaisal jaminan biasanya akan melakukan penilaian dengan berpedoman kepada 2 hal yaitu:, nilai taksiran dan nilai pasar

a) Nilai taksiran adalah nilai harga perkiraan tertentu yang akan dijadikan jaminan yang didasarkan pada harga jadi, pasar dan peraturan yang berkau pada masa tertentu. 
b) Nilai pasar adalah market value yaitu harga barang atau surat berharga yang diindikasikan oleh penawaran pasar, yaitu harga yang tambahan barangnya dapat dijual atau dibeli pada suatu saat, nilai pasar suatu surat berharga ditentukan oleh nilai penjualan terakhir

Dalam perhitungan penilaian jaminan terdapat ketentuan karena jaminan tanah ini ada beberapa hak antara lain; tanah hak milik, tanah hak guna bangunan dan tanah hak sewa. Untuk tanah hak milik pihak bank memberikan nilai $80 \%$. Untuk tanah hak guna bangunan nilainya $80 \%$, jaminan hak sewa itu sekitar 50\%.Karena persentanse tersebut telang menggunakan nilai PBB (pajak bumi dan bangunan) yang biasanya nilainya setengah dari harga pasar dan nilai likuidasinya yaitu saat menjual barang jaminan (untuk nilai ini biasanya sudah diperhitungkan biaya lelang dan biaya notaris), sebaliknya bank jambi jarang menggunakan nilai pasar atau nilai jual sekarang.

\section{Kesesuaian System Dan Prosedur Akuntansi Kredit Produktif Pada PT. Bank Pembangunan Daerah Jambi Cabang Muara Bulian.}

Setelah mengamati pelaksanaan system dan prosedur akuntansi kredit produktif pada Bank jambi telah sesuai dengan Pernyataan Standar Akuntansi Keuangan (PSAK) Nomor 31 tentang Akuntansi Perbankan dan Surat Edaran Bank Indonesia No. 14/26/BKDU tanggal 19 september 2012 tentang prosedur perkreditan, yang mana dalam PSAK tersebut menyatakan bahwa kredit yang diberikan adalah penyediaan uang atau tagihan yang dapat dipersamakan dengan itu, berdasarkan persetujuan atau kesepakatan pinjam meminjam antar bank dengan pihak lain yang mewajibkan pihak peminjam untuk melunasi hutangnya setelah jangka waktu tertentu dengan jumlah bunga, imbalan atau pembagian hasil keuntungan. Termasuk dalam pengertian kredit yang diberikan adalah kredit rangka pembiayaan bersama dan kredit dalam proses penyelamatan. Dan telah sesuai dengan Surat Edaran Bank Indonesia pada pemberian kredit terhadap nasabah/debitur pada PT. Bank Pembanguan Daerah Jambi Cabang Muara Bulian secara efektif \& efesien.

\section{SIMPULAN}

Berdasarkan hasil penelitian dan pembahasan yang telah dikemukakan sebelumnya, penulis dapat menarik kesimpulan, yaitu:

1. PT. Bank Pembangunan Daerah Jambi Cabang Muara Bulian melakukan pemberian kredit yang berawal dari pengajuan kredit, penyerahan persyaratan (kelengkapan identitas, persetujuan keluarga, dokumens ebagai jaminan), dilanjutkan dengan wawancara, hingga melakukan survey lokasi jaminan, dan melakukan akad kredit. Apabila kegiatan tersebut sudah dilaksanakan maka selanjutnya bank jambi akan melakukan pencairan kredit.

2. PT. Bank Pembangunan Daerah Jambi Cabang Muara Bulian melaksanakan tugas yang telah ditetapkan oleh peraturan yang berlaku. Umumnya dalam pelayanan nasabah debitur dan khususnya dalam pemberian kredit dan mengolah agunan/jaminan yang diserahkan oleh debitur sebagai salah satu syarat dalam perjanjian kredit secara efektif dan efesien sesuai dengan prinsip dan peraturan yang berlaku.

\section{DAFTAR PUSTAKA}

Adisetiawan, R., 2018, Does Stock Split Influence to Liquidity and Stock Return? (Empirical Evidence in The Indonesian Capital Market), Asian Economic and Financial Review, 8(5), 682-690.

Adisetiawan, R., 2017, Globalisasi Pasar Modal Dunia dan Pengaruhnya terhadap Pasar Modal Indonesia, Ekonomis: Journal of Economics and Business, 1(1), 10-17

Kusriyanto, Bambang, 1984, Meningkatkan Produktivitas Karyawan, Gramedia: Jakarta

Muchdarsyah, Sinungan, 2005, Produktifitas: Jakarta: Bumi Aksara

Ikatan Akuntan Indonesia, 2002, Pernyataan Standar Akuntansi Keuangan, Salemba Empat, Jakarta

Revianto, 1985, Produktivitas Dan Manajemen, SIUP, Jakarta. 
Surat Edaran Bank Indonesia Nomor 14/26/BKDU tentang Pedoman Kebijakan Dan Prosedur Perkreditan Bagi Bank Perkreditan Rakyat

Undang-Undang Nomor 10 Tahun 1998, Tentang Perubahan Atas Undang-Undang Nomor 7 Tahun 1992 Tentang Perbankan 